ISSN 1112-9867

Available online at http://www.jfas.info

\title{
THE USE OF ORANGE (CITRUS SINENSIS) PEEL AS ANTIMICROBIAL AND ANTI-OXIDANT AGENTS
}

\author{
K. Ould Yerou, K. Ibri, D. Bouhadi, A. Hariri, B. Meddah , A. Tir Touil \\ Laboratory of Bioconversion; Microbiological Engineering and Safety, University of \\ Mascara, Algeria
}

Received: 28 January 2017 / Accepted: 25 July 2017 / Published online: 01 September 2017

\begin{abstract}
Due to rapid growth of the food processing industry and the consumption of processed foods, the demand for natural antimicrobial agents is on the rise. Consumers have become more aware about the health effects of the synthetic preservatives used in food. Hence natural preservatives are developed to meet the demand of consumers. These natural antimicrobials are developed either from plants or their parts, animals or even microorganisms. Even the waste generated from the food industries is being considered as an alternative to produce natural antimicrobials. The aim of the present study was to utilize the waste generated from the citrus fruit processing (peel) industry. This study was to utilize the powder from the peel of Citrus sinensis in food (Oil of olive and cream dessert) to preserve their quality, this peel can be used as antimicrobial and antioxidant activity so food preservation purpose.
\end{abstract}

Key Words: Citrus sinensis peel, powder, food, antimicrobial activity, antioxidant activity

Author Correspondence, e-mail: mhanine11@yahoo.fr

doi: http://dx.doi.org/10.4314/jfas. v9i3.7

\section{INTRODUCTION}

The genus Citrus, belonging to the Rutaceae or Rue family [1], comprises of about 140 genera and 1,300 species. Citrus sinensis (Orange), Citrus paradise (Grapefruit), Citrus limon (Lemon), Citrus reticulate (tangerine), Citrus grandis (shaddock), Citrus aurantium (sour orange), Citrus medica (Citron), and Citrus aurantifolia (lime) are some important fruits of genus Citrus. Citrus are well known as one of the world's major fruit crops that are produced 
in many countries with tropical or subtropical climate. Brazil, USA, Japan, China, Mexico, Pakistan, and countries of the Mediterranean region, are the major Citrus producers. Citrus fruits and their by-products are of high economic and medicinal value because of their multiple uses, such as in the food industry, cosmetics and folk medicine. Anatomically, the fruit consists of two distinct regions, the pericarp, also called the peel, skin or rind, and the endocarp or pulp with juice sac glands. The skin consists of an epidermis of epicuticular wax with numerous small aromatic oil glands that give of its particular smell. The pericarp consists of the outer flavedo or epicarp, largely made of parenchymatous cells and cuticle. The albedo or mesocarp lying beneath the flavedo consists of tubular-like cells joined together to constitute the tissue mass compressed into the intercellular area. The fruit usually contains a sweet pulp and several to numerous seeds within. The fruit pulp is typically formed of eleven segments of juice filled with flavor that goes from sour to sweet. In orchards it is sensitive to frost. [2]

These health benefits are as a result of vitamins, especially vitamin $\mathrm{C}$ [3], phytochemical compounds like liminoids, synephrine, hesperidin flavonoid, polyphenols, pectin.A single orange is said to have about 170 phytonutrients and over 60 flavonoids. [4].

\section{MATERIAL AND METHODS}

The study was conducted in the laboratory of microbiology, university of Mustapha Stambouli - Mascara -Algeria

\section{Plant materials}

Oranges (Citrus sinensis) were purchased from local market (Mascara -Algeria) in February and March 2006.

\section{Samples}

Oil of olive and cream dessert

\section{Methods « AFNOR»}

\section{Preparation of Plant Material}

The peels were carefully washed under running tap water followed by sterile distilled water. These were sun dried for seven days, pulverized to a fine powder using a manual grinder

\section{Preparation of samples of olive oil}

For our analysis Carry on meeting in bottles of olive oil with doses of different powders, bottles are well closed and put in place opaque during 48 hours. 
After the broadcast on a thermal treatment wall -on Samples, the temperatures which are Chosen : $150^{\circ} \mathrm{C}, 200^{\circ} \mathrm{C}$ and $250^{\circ} \mathrm{C}$ during 30 minutes, our samples obtained Cooled and are undergo various analyzes( physical-chimiqual and microbiological) .

\section{Preparation cream dessert}

The custard is produced thick consistency June presenting , made from pasteurized milk , sugar, cocoa, starch and gelling then adding powder orange peel, then applied analyzes (physicochemical and microbiological).

\section{RESULTS AND DISCUSSION}

\section{Results}

The results are presented in tables (1.2.3.4.5.6.7)

Table 1. Peroxide Index

\begin{tabular}{|c|c|c|}
\hline \multirow{2}{*}{$\begin{array}{c}\text { Temperature } \\
(\end{array}$} & \multicolumn{2}{|c|}{ Samples } \\
\cline { 2 - 3 } & Control & With powder of orange peel \\
\hline 150 & 15 & 8,5 \\
\hline 200 & 6,5 & 08 \\
\hline 250 & 5,5 & 06 \\
\hline
\end{tabular}

Table 2. Saponification Index

\begin{tabular}{|c|c|c|}
\hline \multirow{2}{*}{$\begin{array}{c}\text { Temperature } \\
(\end{array}$} & \multicolumn{2}{|c|}{ Samples } \\
\cline { 2 - 3 } & Control & With powder of orange peel \\
\hline 150 & 182,32 & 187,23 \\
\hline 200 & 183,02 & 185,13 \\
\hline 250 & 186,53 & 185,83 \\
\hline
\end{tabular}

We notice that this index in the control increases with increasing temperature but the added sample Orange peel powder, saponification decreases with the increase of the treatment temperature 
Table 3. Acid Index

\begin{tabular}{|c|c|c|}
\hline \multirow{2}{*}{$\begin{array}{c}\text { Temperature } \\
(\end{array}$} & \multicolumn{2}{|c|}{ Samples } \\
\cline { 2 - 3 } $\mathbf{C})$ & Control & With powder of orange peel \\
\hline 150 & 0,44 & 1,24 \\
\hline 200 & 0,96 & 1,48 \\
\hline 250 & 2,28 & 1,72 \\
\hline
\end{tabular}

According to our results, the acid number augments prominently among samples when temperatures rise. This imperative means that olive oil does not remain insensitive to the possible hydrolysis of fats, including glycerides.

Table 4. Total bacteria (CFU / Gx $\left.10^{3}\right)$

\begin{tabular}{|c|c|c|}
\hline \multirow{2}{*}{$\begin{array}{c}\text { Storage time } \\
\text { (days) }\end{array}$} & \multicolumn{2}{|c|}{ Samples } \\
\cline { 2 - 3 } & Control & With powder of orange peel \\
\hline 1st day & 9 & 16 \\
\hline Day 7 & 10 & 04 \\
\hline Day 15 & uncountable & 52 \\
\hline
\end{tabular}

Table 5. Faecal germs (CFU / Gx10 $\left.0^{3}\right)$

\begin{tabular}{|c|c|c|}
\hline \multirow{2}{*}{$\begin{array}{c}\text { Storage time } \\
\text { (days) }\end{array}$} & Control & With powder of orange peel \\
\cline { 2 - 3 } 1st day & 00 & 00 \\
\hline Day 7 & 21 & 02 \\
\hline Day 15 & 66 & 70 \\
\hline
\end{tabular}

Table 6. Psychrotrophs (CFU / Gx $10^{3}$ )

\begin{tabular}{|c|c|c|}
\hline \multirow{2}{*}{$\begin{array}{c}\text { Storage time } \\
\text { (days) }\end{array}$} & Control & With powder of orange peel \\
\cline { 2 - 3 } & 02 & 00 \\
\hline 1st day & uncountable & 63 \\
\hline Day 7 & 37 & 00 \\
\hline Day 15 & & \\
\hline
\end{tabular}


Table 7. Yeasts and molds (UFC/Gx10 $\left.0^{3}\right)$

\begin{tabular}{|c|c|c|}
\hline \multirow{2}{*}{$\begin{array}{c}\text { Storage time } \\
\text { (days) }\end{array}$} & Control & With powder of orange peel \\
\cline { 2 - 3 } & 10 & 00 \\
\hline 1st day & 10 & 10 \\
\hline Day 7 & 140 & 30 \\
\hline Day 15 & & \\
\hline
\end{tabular}

Absence of pathogens: Staphylococcus aureus, Salmonella and Clostridium sulfite reducers. It appears that the heat treatment was effective and good conservation, maintenance at the production line. [5]

\section{DISCUSSION}

Citrus cinensis is a rich source of secondary metabolites which contribute to the pharmacological activities attributed to this plant.

The antimicrobial potency of plants is believed to be due to tannins [6], saponins, phenolic compounds, essential oils [7] and flavonoids. These compounds are known to be biologically active and therefore aid the antimicrobial activities of the plants [8]. These secondary metabolites exert antimicrobial activity through different mechanisms. Tannin as observed in Citrus sinensis peel extract have been found to form irreversible complexes with proline.Citrus plants could be regarded as medicinal due to the high level of flavonoid content in them. [9]

A high quality orange is one that is mature with good color intensity uniformly distributed over the surface. Such oranges must be firm with a fairly smooth texture and shape that is characteristic of the variety, free from decay, defects and other blemishes.

In recent years there has been increasing interest in plant antioxidants because of their potential health-promoting properties. The above antioxidant activities of Citrus cinensis are attributed to the presence of five C-glycosyl flavones: lucenin-2, vicenin-2, stellarin-2, lucenin-2-4'-methyl ether and scoparin; one 3-hydroxy-3-methylglutaryl glycosyl flavonol: 3hydroxy-3-methylglutaryl glycosyl quercetin; and one flavone O-glycosides: chrysoeriol 7-Oneoesperidoside [10]

These group of pigments as found in plants and together with anthocyanin play a role in flower and fruit colouration. Also, they are present in dietary fruits and vegetable, and exercise their antioxidant activity in several ways. Studies indicate that flavonoids are 
excellent radical-scavengers of the hydroxyl radical, due to their to ability to inhibit the hydroxyl radical and donate hydrogen atom. Oranges as excellent source of vitamin C [11] contain powerful natural antioxidant, folate, dietary fiber and other bioactive components, like carotenoids and flavonoids that prevent cancer and degenerative diseases.

\section{CONCLUSION}

Natural products have been and will be important sources of new pharmaceutical compounds. Recently, there has been a renewed interest in natural product research due to the failure of alternative drug discovery methods to deliver many lead compounds in key therapeutic areas. In this sense, considering the health benefits of C. sinensis it presents excellent options for treating or helping in a disease due to its bioactive compounds (drug candidates) that show important activities or for developing new products, there is the need for public enlightenment on the importance of $\mathrm{C}$. sinensis and finding and discovering new and effective drug compounds, so this review represents an excellent source of information about this natural product.

\section{REFERENCES}

[1] Loussert, 1989 : Les Agrumes Volume 2 Production ; ÉDITIONS TEC ET DOC / LAVOISIER .

[2] Bouhadi D, 2000: Development and study of the quality of a new "Carrot -Orange" type and conservation test .Memory for the graduation of an engineer. University of Mascara, Algeria.

[3] Hoffman, D. W., 1971: The Assessment of Soil Productivity for Agriculture. GuelphUniversity.

[4] Guignard, 2000: Biochimie végétale, préface de potier P2ème Edition Dunod ;Paris.

[5] April Jean-Loup, 1997: New dictionary of clinical bacteriology, Ellipses.

[6] Cheftel J-C, Cheftel H and Besancom P, 1977: Introduction to Biochemistry and Food Technology.TEC and DOC.Lavoisier.

[7]Dupaigne P, 1972: Fruit drinks, preparation preservation. French Institute of Fruit Research Overseas.

[8] Oikeh E. I., Oriakhi K. and Omoregie E. S,2013: Proximate Analysis and Phytochemical Screening of Citrus sinensis Fruit Wastes .The Bioscientist: Vol. 1(2):164-170, September, 2013. 
[9] Zebra Chinelo A, Okeke CUand Bibian O, 2014: Flavonoid Content of Citrus Species Grown in Awka, Anambra State, Southeastern Nigeria Aziagba International Journal of Agriculture and Biosciences.

[10] Barreca, D.; Bellocco, E.; Leuzzi, U.; Gattuso, G. 2014: First evidence of C- and O glycosyl flavone in blood orange (Citrus sinensis (L.) Osbeck) juice and their influence on antioxidant properties. Food Chem., 149, 244-252.

[11] Choi M.H, Kim G.H, Lee H.S,2002: Effects of ascorbic acid retention on juice color and pigment stability in blood orange (Citrus sinensis) juice during refrigerated storage Food Research International; Volume 35, Issue 8, 2002, Pages 753-759.

\section{How to cite this article:}

Ould Yerou K, Ibri K, Bouhadi D, Hariri A, Meddah B, Tir Touil A. The use of orange (citrus sinensis) peel as antimicrobial and anti-oxidant agents. J. Fundam. Appl. Sci., 2017, 9(3), 1351-1357. 